\title{
The Role of Adrenomedullin as a Growth Regulatory Peptide in the Normal and Malignant Setting
}

\section{Frank Cuttitta*,1, Luis M. Montuenga ${ }^{\ddagger}$, Mercedes Garayoa*,2, Rubén Pío,,3, Mae Jean Miller*, Thomas Walsh ${ }^{\dagger}$, Ted Elsasser ${ }^{\S}$, and Alfredo Martínez*}

\author{
*Intervention Section, Department of Cell and Cancer Biology, Medicine Branch, \\ Pediatric Branch, Division of Clinical Sciences, National Cancer Institute, Bethesda, MD 20892, \\ Department of Histology and Pathology, University of Navarra, Pamplona, Spain, \\ 31080 and ${ }^{\S}$ Growth Biology Laboratory, USDA, Beltsville, MD 20705
}

\begin{abstract}
Adrenomedullin (AM) is a recently discovered pluripotent peptide initially isolated from a human adrenal gland tumor (pheochromocytoma). Adrenomedullin has been shown to have an ancient origin with immunoreactive species found in mammals, birds, reptiles, amphibians, fish, and echinoderms (starfish). Given its highly conserved evolutionary expression, AM is thought to play a critical role in species survival. This peptide has been shown to mediate a variety of physiological functions, of which its involvement in growth regulation will be the central focus of this paper. In the following text, we will review the cited literature in this area and include our own observations regarding AM expres-
\end{abstract}

sion in carcinogenesis, embryogenesis, and wound repair. Adrenomedullin will be shown to induce both growth promotion or growth suppression depending on the target cell examined and the surrounding nutritional environment in which the analysis was done. Its implied role as a mitogen, angiogenic factor, and apoptosis survival factor will be critiqued and evaluated relative to its importance in the cell proliferation process. Finally, we will review the antimicrobial effect AM has on several human pathogens (Escherichia coli and Candida albicans) and demonstrate its participation in the host immune response system as a first line defense peptide.

Key Words: Adrenomedullin, Peptide, Growth Promotion, Growth Suppression, Cancer

\section{Introduction}

Adrenomedullin ( $\mathbf{A M}$ ) was initially identified as a chromatographic isolate from the acid extract of human pheochromocytoma tissue that was capable of elevating platelet cyclic adenosinemonophosphate (cAMP) and inducing a hypotensive effect in experimental rats (Kitamura et al., 1993a). The cDNA base sequence for mouse, rat, pig, cow, dog (partial sequence), and human message have been determined and the molecular organization of human and mouse genes identified (Kitamura et al., 1993b, 1994; Sakata et al., 1993; Ishimitsu et al., 1994; Okazaki et al.,

\footnotetext{
${ }^{1}$ To whom correspondence should be addressed: Intervention Section, Dept. of Cell and Cancer Biology, Medicine Branch, Building 10, Room 12N226, Bethesda, MD 20892, Tel.: 301-402-3308; Fax: 301-435-8036; E-mail: cuttittaf@bprb.nci.nih.gov

${ }^{2}$ Mercedes Garayoa was supported by a postdoctoral fellowship from Dirección General de Enseñanza Superior, Ministerio de Educación y Cultura, Spain (PF96 0029138440).

${ }^{3}$ Rubén Pío was recipient of a fellowship from Instituto de Salud Carlos III, Ministerio de Sanidad y Consumo, Spain, grant 98/9172.
}

1996; Barker et al., 1998; Jougasaki, 1998). Figure 1 is a schematic diagram that illustrates the transcription and translation products of human AM. For a more detailed description of the human AM information present in this figure, refer to accession number D43639 (gene) or D14874 (mRNA) in the GenBank web page. The AM message is composed of four exons and three introns; however, exon one is not read and only part of exon two, all of exon three and part of exon four are translated into the prepro AM precursor molecule. Several transcription factor response elements have been identified in the $5^{\prime}$ flanking region of the human AM gene, which include AP-1, AP-2 and $\gamma$ IRE sites as well as CRE and SSRE sites in the first intron (Ishimitsu et al., 1994; Minamino et al., 1998). Interestingly, it has been shown that basal expression of AM in human vascular endothelial cells requires a minimum of $110 \mathrm{bp}$ at the $5^{\prime}$ flanking region of the first exon (Ishimitsu et al., 1998). Northern analysis has identified AM message in adrenal glands, lung, heart, brain, pancreas, stomach, intestine, and spleen of several mammalian species (Kitamura et al., 1993b, 1994, 1998; Sakata et al., 1993; Minamino et 


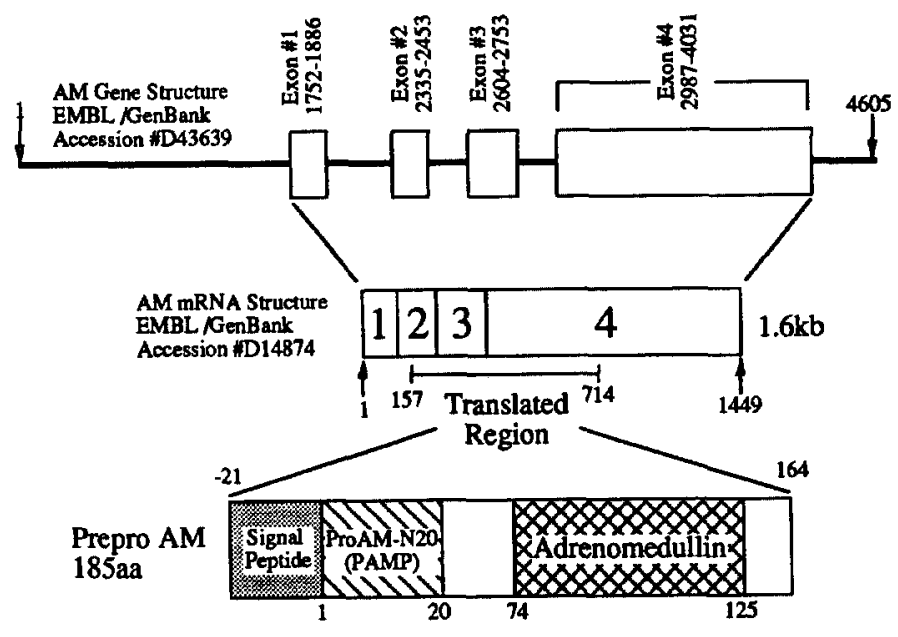

Figure 1. The sequential molecular products (gene/ mRNA/protein) of human adrenomedullin (hAM). The gene for hAM (accession no. D43639) encodes four exons and three introns with a 5 ' promoter region which contains AP-1, AP-2 and $\gamma$-IRE sites (Ishimitsu et al., 1994; Minamino et al., 1998). The hAM message (accession no. D14874) is $1.6 \mathrm{~kb}$ in size and is translated into a 185 amino acid precursor protein that contains two active peptides, AM and PAMP (Kitamura et al., 1993b; Cuttitta et al., 1998).

al., 1998). Parallel findings of AM protein expression in these tissues have been demonstrated by RIA and immunohistochemical analysis (Ichiki et al., 1994; Sakata et al., 1994; Montuenga et al., 1997). Adrenomedullin shares structural homology with calcitonin gene-related peptide (CGRP) and amylin (Kitamura et al., 1998).

Adrenomedullin or AM-like proteins have been detected in both vertebrate (mammals, birds, reptiles, amphibians, fish) and nonvertebrate (echinoderms) species; therefore representing a highly conserved peptide throughout the evolutionary progression of animals (López Diez Del Corral and Cuesta Rubio, 1998). Because of its repetitious expression in the animal kingdom, which dates back 100 million yr or more, AM has been implicated to play some fundamental role in species survival (Cuttitta et al., 1998). This idea has been further substantiated by the fact that AM has been shown to operate as a pluripotent peptide that modulates a variety of physiological functions which include: cardiovascular tone (Ishiyama et al., 1993; Nuki et al., 1993; Lippton et al., 1994; Santiago et al., 1994; Fukuhara et al., 1995; Parkes, 1995), central brain activity (Takahashi et al., 1994; Murphy and Samson, 1995; Martínez et al., 1997c; Samson and Murphy, 1997), bronchodilation (Kanazawa et al., 1994), hormone release (Yamaguchi et al., 1995; Samson et al., 1995; Martínez et al., 1996b, 1998), renal output (Ebara et al., 1994; Jougasaki et al., 1995; Majid et al., 1996), apoptosis (Kato et al., 1997), angiogenesis (Zhao et al., 1998), cell growth (Miller et al., 1998), and immune response (Walsh et al., 1996, 1998; Kubo et al., 1998 a,b; Zaks-Zilberman et al., 1998). In the following text, we will focus on the growth regulatory role that AM plays on cell proliferation, growth cessation, differentiation, embryogenesis, carcinogenesis, immune response, and wound repair. A summary of these findings are presented in Table 1.

\section{Adrenomedullin-Induced Growth Stimulation}

The first demonstration of the ability of AM to stimulate cell growth came from a collaborative study between the Imperial Cancer Research Fund and the Imperial College School of Medicine at the Hammersmith Hospital in London, England. These two groups reported that $A M$ induces a dose-dependent increase in $\left[{ }^{3} \mathrm{H}\right]$-thymidine incorporation and elevates the number of confluent quiescent Swiss 3T3 mouse fibroblast cells cultured under serum-free conditions (Withers et al., 1996). The AM response was augmented synergistically when insulin was added to the cell culture media. These investigators found that AM caused an increase in the intracellular cAMP levels of Swiss 3T3 cells, which was both time and concentration dependent, but had no effect on $\mathrm{Ca}^{2+}$ mobilization. Adrenomedullin had previously been shown to activate $\mathrm{Ca}^{2+}$ mobilization as an alternative signal transduction pathway in bovine aortic endothelial cells (Shimekake et al., 1995). In the Swiss 3T3 model, AM induction of cAMP accumulation was not accompanied by the activation of protein kinase $\mathrm{C}$ ( PKC) or phospholipase C ( PLC), because there was no observed increase in tyrosine phosphorylation of intracellular substrates or alteration in the production of inositol phosphates. The protein kinase A inhibitor H-89 blocked AM induced labeled nucleotide uptake but had no effect on epidermal growth factor driven $\left[{ }^{3} \mathrm{H}\right]$-thymidine incorporation (a non cAMP-dependent process). A Swiss 3T3 cell line that was stably transfected with a constitutively activated Gs $\alpha$ subunit, [Gs $\alpha 92227 \mathrm{~L} \alpha \mathrm{s} 03 \mathrm{~T} 3$ ], expressed a 250-fold increase in sensitivity to AM regulated $\left[{ }^{3} \mathrm{H}\right]$-thymidine incorporation over the wild-type parent with resulting $\mathrm{EC}_{50}$ of $4 \mathrm{p} M$ and $1 \mathrm{n} M$ respectively. Finally, with the use of [125I]-AM and [125I]-CGRP labels, it was determined that Swiss 3T3 cells selectively bind AM and that this receptor/ligand interaction was not disrupted with cold CGRP or CGRP $_{8-37}$ (CGRP antagonist) at concentrations up to $1 \mu M$. These seminal studies by Withers and coworkers were subsequently confirmed 2 yr later by an independent laboratory that identified a putative AM mediated autocrine growth circuit in Swiss 3T3 cells (Isumi et al., 1998a).

Our laboratory has completed a detailed analysis of AM/AM-receptor ( AM-R) expression in the normal/ malignant human lung, determined the subset of cells 
involved, and identified a possible autocrine growth mechanism of the airway (Martínez et al., 1995, 1997b; Miller et al., 1996, 1998). In our initial studies, we demonstrated that a variety of specialized pulmonary cells expressed AM mRNA/protein. These included ciliated/nonciliated epithelium, endothelial cells of the vascular bed, smooth muscle cells surrounding the bronchus, chondrocytes, neurons of the parasympathetic nervous system, and activated alveolar macrophages (Martínez et al., 1995). When examining archival specimens by immunohistochemistry, we found that many pulmonary malignancies derived from the airway epithelium also expressed high levels of AM immunoreactivity (adenocarcinomas, large cells carcinomas, squamous cell carcinomas, and carcinoids) with the exception of small cell carcinomas, which routinely showed a low staining phenotype (Martínez et al., 1995). Similar results were also observed for representative human tumor cell lines of the lung when AM immunoreactivity or AM message were evaluated (Martínez et al., 1995). In addition, we have shown that several other human tumor cell lines of diverse tissue origin also have elevated AM expression, including cancers of the colon, breast, ovary, prostate, brain, cartilage, adrenal gland, blood and skin (Miller et al., 1996, 1998; Martínez et al., 1997a). The vast majority of the above-mentioned cell lines have been shown to express the AM-R message by RT-PCR, thus implicating a potential autocrine growth relationship (Miller et al., 1996; Martínez et al., 1997a). In support of this theory, we have used a neutralizing anti-AM monoclonal antibody (MoAb-G6) to block the cell proliferative effects of endogenous AM in lung, breast, and ovary cancer cell lines (Miller et al., 1996). The growth suppressive effects of MoAb-G6 could be inhibited by the addition of synthetic $\mathrm{AM}$, resulting in the restoration of cell proliferation (Miller et al., 1996). Using a human breast carcinoma cell line (MCF-7) as a model, it was shown that this cancer cell produced and released authentic AM into the conditioned medium when grown in a serum-free environment and selectively bound $\left.{ }^{125} \mathrm{I}\right]-\mathrm{AM}$ at high affinity $\left(\mathrm{K}_{\mathrm{d}}=4 \mathrm{n} M\right)$ with a calculated receptor density of 50,000 sites per cell (Miller et al., 1996). In addition, exogenous AM induced a dose-dependent

Table 1. Adrenomedullin mediated regulation of cell growth

\begin{tabular}{|c|c|c|c|}
\hline Test cell type & Growth effect & $\begin{array}{l}\text { Signal transduction } \\
\text { pathway or } \\
\text { mechanism of action }{ }^{1}\end{array}$ & Reference \\
\hline Mouse fibroblast cell line & Stimulation & cAMP & Withers et al., 1996 \\
\hline Rat fibroblast cell line & Inhibition & ND & Wang et al., 1996a,b \\
\hline Human neuroblastoma cell line & Inhibition & ND & Ando et al., 1997 \\
\hline Human oral keratinocytes cell line & Stimulation & cAMP & Kapas et al., 1997 \\
\hline Human skin melanoma cell line & Simulation & ND & Martínez et al., 1997a \\
\hline Human breast carcinoma cell line & Stimulation & cAMP & Miller et al., 1996 \\
\hline Human ovarian carcinoma cell line & Stimulation & ND & Miller et al., 1996 \\
\hline $\begin{array}{l}\text { Human lung adeno/squamous carcinoma } \\
\text { cell line }\end{array}$ & Stimulation & ND & Miller et al., 1996 \\
\hline Human lung carcinoid cell line & Stimulation & ND & Miller et al., 1996 \\
\hline Human umbilical vein endothelial cells & Stimulation & ND & Zhao et al., 1998 \\
\hline \multirow[t]{2}{*}{ Rat endothelial cells } & Inhibition & cAMP & Nitchibata et al., 1998 \\
\hline & Apoptosis survival factor & ND & Kato et al., 1997 \\
\hline Rat mesangial cells & Inhibition & cAMP & $\begin{array}{l}\text { Chini et al., } 1995 \\
\text { Segawa et al., } 1996 \\
\text { Nitchibata et al., } 1998\end{array}$ \\
\hline \multirow[t]{2}{*}{ Rat vascular smooth muscle cells } & Inhibition (serum) & cAMP & Kano et al., 1996 \\
\hline & Stimulation (serum-free) & MAPK & Iwasaki et al., 1998 \\
\hline Fetal rat osteoblast & Stimulation & ND & Cornish et al., 1997 \\
\hline In vitro cultures of human cytotrophoblast & Differentiation marker & ND & Morrish et al., 1996 \\
\hline \multirow{2}{*}{$\begin{array}{l}\text { Fetal cells during mouse/rat/human } \\
\text { embryogenesis }\end{array}$} & Proliferation and differentiation & ND & $\underline{\text { Montuenga et al., } 1997}$ \\
\hline & & & $\begin{array}{l}\text { Macri et al., } 1996 \\
\text { Di Iorio et al., } 1997\end{array}$ \\
\hline Mouse mammary gland development & Proliferation and differentiation & ND & Jahnke et al., 1997 \\
\hline $\begin{array}{l}\text { Chick chorioallantoic membrane } \\
\text { (neovasculature) }\end{array}$ & Stimulation (angiogenic factor) & ND & Zhao et al., 1998 \\
\hline $\begin{array}{l}\text { Repair of salt/ethanol induced damage of } \\
\text { rat gastric mucosa }\end{array}$ & $\begin{array}{l}\text { Stimulation (promoter of wound } \\
\text { repair) }\end{array}$ & ND & Fukuda et al., 1998 \\
\hline Escherichia coli and Candida albicans & Inhibition (antimicrobial factor) & $\begin{array}{l}\text { Membrane disruption } \\
\text { (pore formation) }\end{array}$ & Walsh et al., 1996, 1998 \\
\hline
\end{tabular}

${ }^{1}$ cAMP $=$ cyclic adenosine monophosphate; $\mathrm{ND}=$ not determined; MAPK = mitogen-activated protein kinase. 
increase in the intracellular cAMP of MCF-7 that could be blocked by MoAb-G6 (Miller et al., 1996). Our collective results strongly suggest that AM may function as an autocrine growth factor for certain human tumors and that it represents an interesting target to evaluate in intervention strategies for the possible disruption of carcinogenesis.

The skin has also been shown to be an anatomical site with extremely high AM transcription/translation product expression (Martínez et al., 1997a). Cells of the integument and their underlying specialized epidermal structures (hair follicles and sweat glands [eccrine or apocrine]) were areas of abundant AM production. In fact, AM levels in sweat were shown to be fivefold higher than concentrations found in the blood with respective mean values of 87.9 and 16.8 $\mathrm{fmol} / \mathrm{mL}$. The labeled ligand $\left[{ }^{125} \mathrm{I}\right]-\mathrm{AM}$ selectively bound normal and malignant human skin cell lines with a $\mathrm{K}_{\mathrm{d}}$ of approximately $9 \mathrm{n} M$ and was not significantly displaced by $\mathrm{AM}_{22-52}$, CGRP, CGRP $8-37$ or amylin at $1 \mu M$ concentration. Exogenous $\mathrm{AM}$ increased the proliferative index of a human melanoma cell line, cultured under .5\% FCS, in a dosedependent manner that approached the growth rate achieved in $10 \%$ FCS. In similar studies using a human oral squamous cell carcinoma line (H357), Kapas et al. (1997) have also demonstrated a mitogenic role of $\mathrm{AM}$ in cells having a keratinocyte lineage. They reported that AM elevated intracellular levels of cAMP in $\mathrm{H} 357$ with a significant inflection at $10 \mathrm{pmol} / \mathrm{L}$ and a maximal fourfold response achieved at $10 \mathrm{nmol} / \mathrm{L}$. In addition, using $\mathrm{H} 357$ as the target cell for $\left.{ }^{125} \mathrm{I}\right]-\mathrm{AM}$ binding studies, these investigators have identified a single population of receptors with a calculated $\mathrm{K}_{d}$ of $8.25 \mathrm{nmol} / \mathrm{L}$ and a $B_{\max }$ of $466 \mathrm{fmol} /$ mg protein. Cold CGRPI, CGRPII, $\mathrm{CGRP}_{8-37}$, and amylin were ineffective in displacing the $\left[{ }^{125} \mathrm{I}\right]-\mathrm{AM}$ label at concentrations exceeding $950 \mathrm{nmol} / \mathrm{L}$. H357 growth induction by exogenous AM, as measured by $\left[{ }^{3} \mathrm{H}\right]$-thymidine uptake, paralleled the cAMP response graph with a measurable proliferation increase (25\% over untreated control, $P<.05$ ) with as little as 10 $\mathrm{pmol} / \mathrm{L}$ of the peptide. The cAMP homolog, dibutyryl cAMP, also caused significant increases in the growth rate of $\mathrm{H} 357$ (twofold elevation), which suggested that AM induced proliferation involved a cAMPdependent mechanism. Interestingly, neither the PKC inhibitor, Ro31-8220, nor the tyrosine kinase inhibitor, lavendustin $\mathrm{A}$, had an effect on AM mediated growth of $\mathrm{H} 357$.

Recent studies by Cornish et al. (1997) have demonstrated that AM can stimulate the growth of rodent osteoblasts in vitro and in vivo (Cornish et al., 1997). At concentrations of $10^{-12} M$ and greater, AM produced a dose-dependent increase in cell number and $\left[{ }^{3} \mathrm{H}\right]$-thymidine incorporation in primary cultures of fetal rat osteoblasts. Peptide fragments of $\mathrm{AM}$ $\left(\mathrm{AM}_{15-52}, \mathrm{AM}_{22-52}\right.$, and $\left.\mathrm{AM}_{27-52}\right)$ with truncated amino terminal end (with or without disulfide loop) were capable of inducing growth. These investigators have also demonstrated that amylin $8-37$ (an amylin antagonist) could effectively block AM stimulated cell proliferation of fetal rat osteoblasts, thus indicating that AM mediated growth effects are regulated through the amylin receptor. When applying similar investigative studies to bone organ cultures of neonatal mouse calvaria that had been prelabeled in vivo with ${ }^{45} \mathrm{Ca}, \mathrm{AM}$ was shown to increase both DNA and protein synthesis without affecting basal bone resorpting rates (release rate of ${ }^{45} \mathrm{Ca}$ remained constant). Finally, local administration of AM to the skullcap of adult mice caused a threefold increase in the index of osteoblast activity in treated hemicalvaria compared to the untreated control side and also increased mineralization of the bone in this region.

While investigating tamoxifen (Txf) induced endometrial hyperplasia in premenopausal women, Zhao et al. (1998) demonstrated, using PCR differential display, that this nonsteroidal antiestrogen stimulated AM message expression in normal human endometrial stromal cells. Based on these data, these investigators began to evaluate the possibility that AM may underlie Txf induced endometrial hyperplasia. Toward this end, Zhou et al. (1998) examined the mitogenic effects of AM on primary cultures of human umbilical vein endothelial cells (HUVEC) grown in the presence of $10 \%$ FCS. Adrenomedullin (10 $\mathrm{nM}$ ) was shown to give a comparable growth promoting response as basic fibroblast growth factor (at similar molar concentration) on cultured HUVEC resulting in a twofold increase in the proliferative index over a $6 \mathrm{~d}$ evaluation period. In addition, AM was demonstrated to be an angiogenic factor in a chick chorioallantoic membrane assay, which caused significant increases in neovascularization $(P<.005$ to $P<.05)$ over the dose range of $10 \mathrm{p} M$ to $1 \mathrm{n} M$. The mitogenic features and angiogenic capability of AM have been implicated by Zhao et al. (1998) as a possible autocrine/paracrine mechanism regulating Txf induced endometrial polyp formation or uterine neoplasia expression.

In a recent seminal report by Iwasaki et al. (1998), AM was identified as a growth-promoting factor for primary cultures of rat vascular smooth muscle cells (VSMC) grown under serum-free conditions. Adrenomedullin was shown to increase DNA synthesis and cell number of quiescent VSMC over a test concentration of $1 \mathrm{n} M$ to $1 \mu M$. CGRP gave a similar but less potent growth response when evaluated at the same concentration range. The peptide antagonist CGRP $_{8-37}$ suppressed the growth stimulatory effects of both AM and CGRP on quiescent VSMC targets implicating the involvement of a common receptor. The activity of $\mathrm{p} 42 / \mathrm{p} 44$ mitogen-activated protein kinase (MAPK), a member of the serine/threonine kinases family, in quiescent VSMC was upregulated in a dose-dependent and time-dependent manner by AM. 
Adrenomedullin induced activation of MAPK was not affected by 8-bromo-cAMP, forskolin, a cAMP antagonist (Rp-cAMP-thionate), nor by the PKA inhibitor (KT5720), thus appearing to involve a cAMPindependent regulatory mechanism. In addition, AM was shown not to invoke a $\mathrm{Ca}^{2+}$ mobilization response nor alter inositol phosphate levels in VSMC, and the PKC inhibitor (GF109203) did not block AM induced MAPK activation. These data suggest that AM mediated growth of quiescent VSMC is not controlled through PKC or PLC pathways. Interestingly, the growth-promoting effects of AM were accompanied by the transactivation of the early response gene $c$-fos. In order to dissect crucial areas of the MAPK cascade required for AM modulation of VSMC growth, these investigators used the MAPK kinase ( MEK) inhibitor PD98059 which blocked AM activation of MAPK, suppressed AM induction of $c$-fos expression and muted AM growth stimulation of the target cell. Along similar lines, it was found that the protein tyrosine kinase ( PTK) inhibitor genistein or ST630 completely blocked AM induced MAPK activation and suppressed the proliferative effects of AM on VSMC, thereby identifying a previously unknown pathway by which AM regulates cell growth. One of the most interesting findings to emerge from this study was that AM could have diametrically opposed growth effects in the same model system depending on the environmental conditions. As will be discussed in the next section, AM has been previously shown by Kano et al. (1996) to inhibit the growth of rat VSMC under serum supplemented conditions, whereas the work of Iwasaki et al. (1998) demonstrates the opposite effect, in which AM mediates growth-promotion in rat VSMC cultured in the absence of serum.

\section{Adrenomedullin-Mediated Growth Suppression}

In the previous section, we reviewed the reported literature in support of $\mathrm{AM}$ as a mitogenic factor capable of driving cell growth in a variety of mammalian cell systems; we will now present the paradoxical side of this pluripotent peptide, which implicates $A M$ as a growth cessation factor. The first report to clearly demonstrate a growth suppressive effect for AM was authored by Chini et al. (1995), who evaluated the peptide in a primary culture of rat mesangial cells ( rMC). Previously, these investigators had shown that elevations in intracellular cAMP could block the basal or mitogen-induced growth of rMC (Matousovic et al., 1995). Applying a similar experimental strategy to study AM-mediated growth effects on rat kidney reticuloendothelial cells, these investigators showed that the peptide, through "negative crosstalk", inhibited the MAPK signal transduction cascade, thereby suppressing cell proliferation
(Chini et al., 1995). At a dose range of 1 to $100 \mathrm{n} M$, AM was shown to activate cAMP-dependent protein kinase A (PKA), which, in turn, could potentially phosphorylate the regulatory domain of Raf-1 (Chini et al., 1995; Wu et al., 1995). Prior studies in this area had revealed that phosphorylation of the catalytic domain of Raf- 1 caused the inhibition of its protein kinase activity, thereby blocking MAPK and resulting in the suppression of mitogen-induced growth (Graves et al., 1993; Marx, 1993; Sevetson et al., 1993; Cook and McCormick, 1993; Wu et al., 1995). Adrenomedullin blockade of rMC growth has been proposed by Chini et al. (1995) to involve a similar Raf-1 dependent mechanism. Expanding this initial study, Chini and coworkers (Chini et al., 1996) have shown that AM does not inhibit all types of mitogen-induced growth. Interestingly, even though AM will suppress platelet-derived growth factor (PDGF) and epidermal growth factor ( EGF) mediated proliferation of rMC, it does not inhibit endothelin-1 (ET-1) induced growth. Although all three cytokines activate MAPK, the selective AM inhibition of mitogen-induced mesangial cell growth is thought to involve different isomers of Raf-1. Ventricular myocytes have been previously shown by Bogoyevitch et al. (1995) to contain two isoforms of Raf, denoted as c-Raf (or Raf-1) and ARaf, ,which were differentially regulated by fibroblast growth factor (FGF) (c-Raf activation) and ET-1 (cRaf and A-Raf activation). Although PKA could inhibit c-Raf activity, it was far less effective in inhibiting A-Raf activation (Bogoyevitch et al., 1995). Chini et al. (1996) have used this relationship of different isoforms of Raf to explain their data on selective AM inhibition of mitogen-induced $\mathrm{rMC}$ growth. They propose that PDGF/EGF utilize the cRaf isoform similar to FGF (blocked by AM/PKA), whereas in the case of ET-1, although c-Raf is activated (AM/PKA suppressive isoform), it is the PKA resistant isoform A-Raf that drives MAPK activation in the presence of AM (Chini et al., 1996). A recent report from Shiga University of Medical Science is in direct conflict with the observations of Chini, given that this group has demonstrated the ability of AM to inhibit ET-1 induced MAPK activity in rMC (Haneda et al., 1996). As a final note to these types of studies, it has been shown by Segawa et al. (1996) that AM can suppress serum induced growth of $\mathrm{rMC}$ through a cAMP-dependent pathway.

We have previously discussed the proliferative action that AM can convey to rat VSMC (ending paragraph of the prior section) and will now review its growth suppressive effect in this same cell system. There have been several reports in the literature which demonstrate AM-R expression in VSMC (Eguchi et al., 1994a,b; Ishizaka et al., 1994). Kano et al. (1996) have found that exogenous AM can block the trophic effects of serum on VSMC in a time/ concentration dependent manner by elevating in- 
tracellular cAMP levels. At a post-treatment time point of $24 \mathrm{~h}, \mathrm{AM}\left(10^{-7} \mathrm{~mol} / \mathrm{L}\right)$ caused an approximate $50 \%$ reduction in the serum induced growth of rat VSMC as assessed by thymidine incorporation. Forskolin and 8-Br-cAMP were shown to mimic the inhibitory response of AM on serum driven growth in VSMC. The growth suppressive effects of AM on rat VSMC was abolished by the CGRP antagonist $\left(\mathrm{CGRP}_{8-37}\right)$, implying that a common receptor mediated the peptide induced inhibition of serum promoted cell proliferation. This result is consistent with the data of Ishizaka et al. (1994), who reported that CGRP $_{8-37}$ could block AM mediated increases in intracellular cAMP for rat VSMC. Interestingly, AM has been shown to induce G0 to G1 cell cycle progression in synchronized VSMC, which is associated with the induction of $c$-fos and AP-1 activation, events normally attributed to cell growth but also known to involve growth suppression via differentiation (Kobayashi et al., 1995; Sato and Autelitano, 1995). The ability of AM to trigger early response gene $c$-fos mRNA expression in VSMC was inhibited by the PKA blocker analogue $\mathrm{H}-89$, which is in line with previously discussed data by Chini et al. (see above) (Chini et al., 1995; Sato and Autelitano, 1995).

Early in the developing field of AM studies, it was reported that vascular endothelial cells (VEC) produced AM mRNA and actively secreted authentic peptide (Sugo et al., 1994a). This discovery was shortly followed by an article by Kato et al. (1995) describing AM binding sites being present on human VEC. When AM was added to cultures of human VEC at concentrations of $10^{-10}$ to $10^{-6} M$, an exponential increase in intracellular cAMP was noted. CGRP was also shown to increase cAMP in this cell system but at a molar potency that was $1000 \times$ less than that observed for AM. Interestingly, $\mathrm{CGRP}_{8-37}$ could significantly block, at equimolar concentrations, the CGRP mediated increase in cAMP but was unable to affect AM induced elevation of cAMP. These data suggested the existence of two independent receptors, one of which was specific for AM and the other having a preference for CGRP. Thus, the combined AM data presented thus far implicates the possibility of an autocrine/paracrine mechanism functioning in human VEC. Several recent findings have confirmed this hypothesis. Isumi et al. (1998b) have shown that certain proinflammatory cytokines [tumor necrosis factor ( TNF) $-\alpha$ and interleukin ( IL)-1] can significantly increase $(P<.01)$ AM production in rat VEC whereas TGF- $\beta$ suppresses AM synthesis in these cells. This finding suggests that during bacterial infection (sepsis), the VEC may play a role in regulating homeostasis of vascular tone. Work by Michibata et al. (1995, 1996, 1998), using a neutralizing anti-AM monoclonal antibody, has determined that immuno-blockade of endogenous AM caused basal
cAMP levels to decrease and DNA synthesis to increase in VEC, VSMC, and MC, thus implicating an autocrine/paracrine growth regulatory role for $\mathrm{AM}$ in all three cell types.

\section{Adrenomedullin in Embryogenesis, Organogenesis, and Differentiation}

Initial studies from our group demonstrated spatiotemporal AM/AM-R expression during mouse and rat embryogenesis (Montuenga et al,, 1997). Immunohistochemistry and in situ hybridization confirmed colocalization of AM transcriptional/translational products at distinct anatomical sites. The developing heart was the first organ to express abundant amounts of AM at embryonic day (E) 8 followed by the neovasculature, brain, spinal cord/dorsal root ganglia, lung, skin, liver, intestine, and kidney (E10 to E14). Interestingly, there were specialized areas of cellular development at sensory sites that also showed high AM expression that included the cochlear epithelium of the ear (E12), nasal epithelium ( $E 12$ ), hair follicle (E13), and retina (E15). Noted throughout the organogenesis process was the fact that as undifferentiated mesenchymal cells begin to coalesce/ condense into distinctive specialized cell structures AM/AM-R expression in that area increases. As the differentiation/maturation process continues, the level of AM production increases to a maximum and then progressively decreases to concentrations observed in neonate/adult tissue. Dramatic changes in the AM levels at a given anatomical site can take place in a matter of days. Take for example, the maturation process of the dorsal root ganglia, where, at E11, only the neural prolongations express detectable AM, by E12 several neurons of the ganglion itself begin to show AM production, and by E14 the entire structure develops intense staining for AM. Similar data have been observed in the formation of the cartilaginous templates that precede bone: the more mature chondrocytes (hypertrophic cells) have elevated AM/AM-R expression whereas the newly formed chondrocytes have almost undetectable levels. In these previously discussed tissue sites there appears to be a direct correlation between AM/AM- $R$ expression and the growth/differentiation processes observed during embryogenesis.

Early in embryogenesis (E9) high levels of AM/AM$R$ were expressed at the ectoplacental cone, site of implantation, where fetal trophoblastic giant cells interact with maternal decidual cells. Neovascularization occurs at this area to establish the placental capillary bed, which supplies nutritional sustenance for the developing fetus. Because AM has been reported to be a mitogenic factor and an angiogenic factor (Withers et al., 1996; Zhao et al., 1998), the ectoplacental cone would be an obvious anatomical 
site for elevated AM/AM-R expression. Interestingly, recent studies by Morrish et al. (1996) have indicated that AM may be an early genetic marker for epidermal growth factor (EGF) induced in vitro differentiation of human cytotrophoblasts. Previously, it had been shown that human placental cytotrophoblasts differentiate by fusion to form a multinucleated syncytium and that this process could be mimicked in vitro in a cytotrophoblast culture system (Gerbie et al., 1968; Morrish et al., 1987). Morrish et al. (1987) had previously demonstrated that EGF could stimulate giant cell formation (differentiation) in cultured human cytotrophoblasts. An evaluation by subtractive hybridization of EGF treated vs untreated cytotrophoblasts (freshly isolated from human placenta) showed that in vitro induction of differentiation accompanied elevations in AM mRNA expression (Morrish et al., 1996).

There are several aspects of the implantation process that parallel the events associated with tumor cell invasion into the substroma matrix during carcinogenesis (Yagel et al., 1988; Graham and Lala, 1991). Implantation involves two key progressional steps: 1) migration/intercalation of the fetal trophoblast into the maternal tissue through the action of plasminogen activators and matrix metalloproteases (Ray and Stetler-Stevenson, 1994; Harvey et al., 1995); and 2) neovascularization induced by a variety of angiogenic factors, such as vascular endothelial growth factor (VEGF), transforming growth factor$\beta$ ( TGF- $\beta$ ) and AM, to accommodate nutritional support and waste removal for the developing fetus (Roberts et al., 1986; Ryan et al., 1998; Zhao et al., 1998). Both of these steps have also been shown to play a critical role in the tumor invasion process (Ray and Stetler-Stevenson, 1994; Harvey et al., 1995; Roberts et al., 1986; Ryan et al., 1998; Zhao et al., 1998). Interestingly, we have recently demonstrated the coordinate expression of TGF- $\beta 1$ and AM during rodent embryogenesis, in particular at the ectoplacental cone, which may reflect concomitant involvement of these two peptides in growth/angiogenesis/differentiation pathways (Montuenga et al., 1998).

We have identified AM expression in secondtrimester human amniotic fluid and amniotic membranes, suggesting that this peptide may be involved in the maintenance of normal pregnancy (Macri et al., 1996a). Similar findings have been observed for the maternal decidual cells in the first trimester (Macri et al., 1996b). These data are consistent with the findings of Di Iorio et al. (1997, 1998), who demonstrate elevated AM plasma levels in pregnant women when compared to nonpregnant controls, and who have observed a dramatic diminution in AM plasma concentration (50\% reduction) $48 \mathrm{~h}$ postpartum. Almost identical findings, regarding AM plasma level fluctuations, have been reported for pregnant rats (Kaufman et al., 1998). Interestingly, AM has also been implicated in preeclampsia syndrome; however, there is still controversy over whether low plasma levels of this peptide in the mother directly initiate this condition or high levels reflect a maternal compensatory response (Lauria et al., 1996a,b; Hata et al., 1997; Di Iorio et al., 1998).

Finally, taking a more global look at AM in the female reproductive tract and in mammary gland development, it is becoming increasingly clear that this peptide must play a critical role in the physiology of these tissues (Jahnke et al., 1996, 1997; Macri et al., 1998). Jahnke et al. have demonstrated that in the sexually immature mouse, the vaginal epithelium is devoid of AM expression. However, after estrogen treatment, a time-dependent increase in AM (mRNA and protein) was noted in the vagina, which was observed as early as $6 \mathrm{~h}$ and maintained for $48 \mathrm{~h}$ (Jahnke et al., 1996). Similar estrogen induced increases in AM levels were also noted in the uterus and myometrium. This same group has done an extensive immunohistochemical/in situ hybridization/ Northern blot study on AM in the human female reproductive tract (ectocervix, endocervix, endometrium, myometrium, ovary, and fallopian tube), which strongly suggests a menstrual phase dependency of expression (Macri et al., 1998). These investigators have demonstrated not only shifts in staining intensity of AM but also alterations in intracellular localization being dependent on cyclic regulation. In general, throughout the reproductive tract highly intense cytoplasmic immunostaining for AM was observed during the proliferative phase, which drops off dramatically during the secretory phase and translocates to the nucleus. These data, in combination with findings from other laboratories (Jahnke et al., 1996), support hormonal control of AM expression in the female reproductive tract and given the cytoplasmic/nuclear translocation shifts observed implicate a possible role for $\mathrm{AM}$ as a transcription factor in gene regulation (Macri et al., 1998). The developing mammary glands are also known to be under hormonal control during the sexual maturation process. Jahnke and coworkers have examined AM/ AM-R in mouse mammary gland and reported an estrogen dependent increase in message expression in that tissue (Jahnke et al., 1997). During the second third of embryo development (E 14), AM mRNA levels drop compared to amounts observed for 15-mo virgins and the AM- $R$ message remains constant with virgin controls; however, AM levels rapidly rise by the 18th $d$ of lactation. In addition, when evaluating hormonal control of AM/AM-R expression in the mammary gland of ovariectomized mice, it was shown that estrogen treatment enhanced expression, progesterone had little effect, but a combination of estrogen/progesterone caused a synergistic elevation in AM message (Jahnke et al., 1997). Immunohistochemical and in 
situ RT-PCR analysis detected AM in the luminal epithelium of small and large ducts and in terminal end buds. Highest intensity staining was observed during lactation, where the epithelium of inflated ducts and the milk itself expressed positive immunoreactivity. When the milk was examined by polyacrylamide gel electrophoresis followed by immunoblotting, authentic AM (6,000 MW) was identified. Given that AM can regulate growth, control gut function (Martínez et al,, 1997c) and assert a protective role against microbial pathogens (see subsequent section on AM as an antimicrobial peptide), its importance in mother's milk seems directly related to a beneficial support mechanism for the neonate.

\section{Adrenomedullin in Apoptosis}

An extremely interesting finding by Kato et al. (1997) is the autocrine/paracrine role that AM plays as an apoptosis survival factor for rat aortic endothelial cells ( rEC) cultured under serum-free conditions. These investigators showed that both endogenous and exogenous AM protected $\mathrm{rEC}$ from apoptosis induced by serum deprivation. Under the harsh growth conditions of a serum-free environment, approximately $40 \%$ of the seeded rEC undergo apoptosis as determined by counting detached cell population via Coulter Counter, detecting cells with single stranded DNA staining (SSDS) and measuring nucleosomal ladder formation ( NLF). Exogenous AM suppressed apoptosis in a concentration- and timedependent manner. A linear protection effect was seen over an AM dose range of $10^{-10}$ to $10^{-6} \mathrm{M}$, with a $50 \%$ reduction in apoptosis observed at $1 \mu M(P<.01)$, dramatically decreasing SSDS and diminishing NLF. The AM apoptosis survival effect was shown not to involve cAMP, $\mathrm{Ca}^{2+}$ mobilization, or PI turnover. In addition, this protective effect was not attributed to an increase in cell proliferation, as AM did not stimulate $\mathrm{rEC}\left[{ }^{3} \mathrm{H}\right]$-thymidine incorporation over the experimental conditions examined. As a further extension of their original observations, Kato et al. (1997) have determined that $\mathrm{rEC}$ express a single population of $A M$ receptor $\left(K_{d}=77 \mathrm{nM}\right)$ with a calculated receptor density of 480,000 sites per cell. Nutritionally stressed $\mathrm{rEC}$ were shown to produce/release endogenous AM into the serum-free conditioned medium and expressed the $1.6 \mathrm{~kb} \mathrm{AM}$ message. As a final experimental exercise to this study, Kato et al. (1997) evaluated rabbit anti-AM polyclonal antisera, in which exposure to $1.0 \%$ preimmune serum prevented the apoptotic event whereas immune serum, at the same concentration, abrogated this protection, implicating an autocrine/paracrine role for endogenous AM in suppressing programmed cell death.

\section{Adrenomedullin in Carcinogenesis}

Based on its initial isolation from a human pheochromocytoma tumor (Kitamura et al., 1993a), there has always been an inherent relationship of $A M$ with cancerous tissue. We have previously discussed the findings from our laboratory and collaborators that identify AM/AM-R expression in pulmonary tumors, cervical/ovarian carcinomas, and in a variety of human tumor cell lines of diverse tissue origin (Martínez et al., 1995, 1997b; Miller et al., 1996; Macri et al,, 1998). Additionally, we have demonstrated the potential for AM mediated autocrine growth of lung, breast, ovary, skin, and glioma tumor cells (Miller et al., 1996; Martínez et al., 1997a; Moody et al., 1997). Several other laboratories have identified AM expression in human colorectal carcinoma cells, human leukemia cell lines, adrenal tumors, ganglioneuroblastomas, neuroblastomas, and glial cell tumors (Satoh et al., 1995, 1997; Takahashi et al., 1997; Kubo et al. 1998a; Nakayama et al., 1998). Consistent with these collective findings is the report by Ehlenz et al. (1997), who observed elevated AM levels in the plasma of patients with lung and gastrointestinal cancers.

Recent studies by Wang, Peters, and Taparowsky from Purdue University have identified the possibility of oncogene regulated AM expression in transformed cells (Wang et al., 1996a,b; Peters et al., 1997). When comparing a rat fibroblast line $(10 \mathrm{~T} 1 / 2)$ to a v-myc transfected derivative ( $m y c$ neo 13A) by PCR-based mRNA differential display technique, these investigators found that AM mRNA was down-regulated in the $v-m y c$ overexpressing line. Northern blot analysis using full length rat AM mRNA probes confirmed the expression of AM message in $10 \mathrm{~T} 1 / 2$, whereas in the myc neo $13 \mathrm{~A}$ it was lacking. Using an AM promoter/ luciferase reporter gene construct, it was shown that a cis-acting DNA element in the AM promoter was responsible for $\mathrm{v}-m y c$ down-regulation of $\mathrm{AM}$ expression. These investigators have also discovered that transfecting 10T1/2 with other transforming oncogenes (H-ras or E1A) could down-regulate AM expression. Interestingly, in dual transfected cells, the constitutive expression of AM could partially inhibit H-ras driven cellular transformation. Oncogene suppression of AM expression may underlie the hyperproliferative state of tumor cells (see AM mediated growth suppression section of this text).

One of the most interesting findings regarding AM/ tumor cell relationships is the recently discovered fact that both AM and its gene-related peptide (PAMP) inhibit the proliferation of human neuroblastoma cells (Ando et al., 1997). Ando et al. (1997) demonstrated that these peptides induced growth inhibition via separated receptors. $\mathrm{CGRP}_{8-37}$ and $\mathrm{AM}_{22-52}$ blocked AM suppression of cell growth but did not affect PAMP activity. In addition, pertussis toxin and $\omega$ - 
conotoxin GIVA blocked the effect of PAMP but not that of AM. These collective data indicate that PAMP inhibits the growth of neuroblastoma cells by suppressing $\mathrm{N}$-type $\mathrm{Ca}^{2+}$ channels through a pertussis toxin-sensitive $G$ protein-coupled receptor and that AM growth suppression is mediated through a different receptor/signal transduction pathway.

\section{Adrenomedullin in Wound Repair}

We have previously discussed the ability of AM to regulate growth (stimulate/suppress) and modulate angiogenesis; these complementary biological events are critical for wound repair. There have been two recent reports that support AM/AM-R expression and interaction as being important in the repair of salt or ethanol induced gastric mucosa damage (Fukuda et al., 1998; Wang et al., 1998). Prior studies have identified the stomach as being an anatomical site for AM expression (Washimine et al., 1995; Mulder et al., 1996). In addition, there are some reports that show peptide/receptor segregation in the stomach, where a discrete population of cells at the neck of the gastric gland express AM, whereas the chief cells (bottom of the gland) have abundant AM-R message (Martínez et al., 1996a; Tomikawa et al., 1998). Fukuda et al. (1998) demonstrated that AM promotes the epithelial restitution of rat and human gastric mucosa in vitro. These investigators have used isolated mucosal strips from the fundic gland area, placed in a Ussing chamber, to measure AM mediated recovery of the gastric mucosa to hyperosmolar shock treatments. The degree of salt induced damage was assessed by measuring the decrease in potential difference (PD), short circuit current (Isc), and mucosal resistance (Rt). Preexposure of test tissue (rat or human) to AM prior to salt damage $(.5 M \mathrm{NaCl})$ resulted in truncated recovery times for $\mathrm{PD}$, Isc, and Rt to return to normal levels, implicating $\mathrm{AM}$ as an enhancer of mucosal repair to mild hyperosmolar shock. Studies by Wang et al. (1998) have examined phenotypic shifts in the intensity of AM/AM-R expression at the periphery of necrotic zones triggered by ethanol induced damage to the gastric mucosa. Their data suggest that AM/AM-R levels increase at proliferative epithelial borders that surround the necrotic lesion during the repair process, and suggest that these events play a critical role in the wound healing mechanism of the gut.

In our extensive analysis of AM/AM-R expression in the lung, we have shown that the ciliated columnar cells of the bronchi/bronchioli have dense apical immunostaining for the peptide ligand and positive in situ RT-PCR for AM mRNA, while being devoid of AM$R$ message (Martínez et al., 1995, 1997b). Conversely, the progenitor cells (basal cells) of the pulmonary epithelium are lacking in AM expression, however, have high AM-R expression (Martínez et al., 1997b). Thus, in the lung there appears to be a clear anatomical segregation of AM/AM-R expression between differentiated and undifferentiated pulmonary epithelial cells. We have proposed that this physical separation between cell types may involve paracrine modes of action during wound repair. Because AM producing cells line the upper airway and this peptide appears to be released into luminal spaces along mucosal surfaces, it is assumed that bronchial secretions would be laden with AM similar to what has been observed for lactating mammary epithelial ducts (Jahnke et al., 1997). Thus if pulmonary damage occurs (infection, chemical, or physical injury) and injured outer epithelial surfaces are sloughed, exposing underlying progenitor cells, the surrounding microenvironment would constitute an ideal medium to drive the repair process given the mitogenic/ angiogenic capabilities of AM. As healing continues and the basal cells are once again separated from outer mucosal surfaces due to cellular differentiation, AM availability would be suppressed and growth terminated. This hypothetical mechanism of normal pulmonary wound repair could also drive carcinogenesis, as transformed pulmonary cells express both AM and AM-R (Miller et al., 1996). Thus, once the physical separation of AM/AM-R breaks down and this theoretical internal control mechanism of the lung is disrupted, constitutive growth of cancer cells could occur. Further investigations are required to validate this proposed possibility underlying lung repair and carcinogenesis, which could have therapeutic implications in defining new strategies against cancer and degenerative pulmonary diseases.

We have recently shown that TGF- $\beta 1$ and AM are coordinately expressed during rodent embryogenesis (Montuenga et al., 1998). Both TGF- $\beta 1$ and AM are known to play a critical role in growth, angiogenesis and differentiation (Roberts, et al., 1986; Miller et al., 1998; Montuenga et al., 1998). Work published by Kane et al. (1991) has demonstrated the spatial/ temporal expression of TGF- $\beta 1$ in cutaneous wound healing. They have shown, through selective immunostaining techniques, that normal skin has abundant amounts of TGF- $\beta 1$ intracellularly expressed (inactive type) which is enzymatically altered to a modified state (active form) by a leupeptin/EDTA sensitive protease during the wound repair process. Kane and coworkers (1991) have determined that active TGF- $\beta 1$ is rapidly produced at the injury site, shows up early in basal keratinocytes, but later is suppressed in these cells and found in blood vessels and papillary dermis, highly expressed at the leading edge of the migrating epithelial sheet, and finally is shut off as the wound healing response is resolved. They propose that active TGF- $\beta 1$ drives chemotaxis, proliferation, and differentiation during the wound repair process. We have recently reported the skin to 
contain high amounts of AM/AM-R, which we believe play an important role in repair of injury and suppression of bacterial infection (Martínez et al., 1997a). Given that TGF- $\beta 1$ and AM are coordinately expressed during fetal development, it will be interesting to determine whether a similar relationship is observed for AM/TGF- $\beta 1$ expression in the skin while cutaneous wound repair occurs.

\section{Adrenomedullin as an Antimicrobial Peptide}

When reviewing the collective information presented in this text, it becomes apparent that AM is a ubiquitous peptide found throughout all major epithelial surfaces (integument, respiratory, alimentary, and genitourinary tracts) and associated with activated macrophages (Martínez et al., 1995; Zhao et al., 1998), which implicates it as a possible antimicrobial peptide similar to magainins, tracheal antimicrobial peptide (TAP) and lingual antimicrobial peptide ( LAP) (Zasloff, 1987; Diamond et al., 1991; Schonwetter et al., 1995). There is an enormous amount of investigative data in the literature to support this line of thought, which identifies $A M$ as an acute response peptide to bacterial invasion or endotoxic shock. Earlier reports by Sugo et al. (1994b, 1995) revealed that lipopolysaccharide (LPS), IL-1, and TNF- $\alpha /$ TNF- $\beta$, biological entities associated with heighten immune response, could actively induce AM expression in rat VSMC. Similar LPS/IL-1/TNF mediated AM expression has been observed for rat endothelial cells (Isumi et al., 1998b). Recent studies by Kubo and coworkers (Kubo et al., 1998a,b) have shown that LPS can stimulate the expression of $A M$ in peritoneal macrophages and macrophage cell lines. In addition, they have demonstrated that in the absence of endotoxin, AM stimulates TNF- $\alpha$ expression in the murine macrophage cell line RAW 264.7. Conversely, AM introduced at $1 \mu M$ concentration dramatically suppresses LPS-induced TNF- $\alpha$ production in this line (Kubo et al., 1998b). These seminal studies by Kubo et al. suggest the possibility of AM acting as an autocrine regulator of the immune response mechanism. Very similar findings have been reported by Zaks-Zilberman et al. (1998), which independently confirm the initial observations by Kubo's group. Their studies also showed that the antitumor agent paclitaxel (Taxol) could increase $A M$ production in peritoneal macrophages from the LPS responsive mouse strain, $\mathrm{C} 3 \mathrm{H} / \mathrm{OuJ}$, but not macrophages taken from the LPS hyporesponsive (Lps mutant) mouse strain, $\mathrm{C} 3 \mathrm{H} / \mathrm{HeJ}$. In addition, they found that AM levels were increased in macrophages taken from both mice strains when exposed to soluble Toxoplasma gondii tachyzoite antigen or the synthetic antitumor agent 5,6-dimethylxanthenone- 4-acetic acid (a flavone analog). When protein synthesis of C3h/OuJ macrophages was blocked with cycloheximide, Zaks-Zilberman et al. (1998) found that the basal level of AM mRNA was increased indicating the normal existence of a suppressor molecule, which down-regulates the steady-state expression of AM message. In the experimental rat model, intravenous injections of bacterial endotoxin resulted in augmentation of AM plasma levels and increased AM mRNA expression in liver, heart, aorta, ileum, and kidney (Shoji et al., 1995; So et al., 1996). Along these same lines, clinical assessment of septic shock patients revealed AM plasma concentrations which were 10 to 15 times higher than normal controls and AM urine levels were elevated in children with urinary tract infections (Hirata et al., 1996; Nishio et al., 1997; Dotsch et al., 1998). Given the cumulated evidence regarding $\mathrm{AM}$ responses to bacterial endotoxin in laboratory animals and humans, it becomes increasingly evident that this peptide may encompass some type of host protection against microbial pathogens.

We have demonstrated that $\mathrm{AM}$ and its gene related peptide, proadrenomedullin $\mathrm{N}$-terminal 20 peptide (PAMP), can function as antimicrobial peptides with defensin-like qualities capable of suppressing the growth of Escherichia coli and Candida albicans (Walsh et al., 1996, 1998). Both peptides showed a concentration- and time-dependent inhibition of growth (direct killing effect) for these opportunistic human pathogens using either a microdilution or macrodilution assay. Germination of C. albicans was also inhibited by these peptides. It was determined that peptide fragments of either AM or PAMP showed drastically reduced ability to suppress microbial growth, thus demonstrating the critical importance of intact molecules for host protection. Biochemical/structural analysis of AM and PAMP has shown these peptides to be highly charged (respective PI of 9.7 and 11.1) with extensive amphipathic regions that permit membrane intercalation leading to pore formation similar to other antimicrobial peptides such as magainins, cecropins, and melittin (Bechinger, 1997). The ability of AM and PAMP to form ion-channels (membrane pores) in $E$. coli and $C$. albicans was determined first by fluorescent probe permeability assay and secondly by measuring cation efflux with atomic absorption spectroscopy. Once membrane integrity is disrupted and selective permeability lost, the effected pathogens are rapidly lysed in this hostile environment.

There are indeed several interesting aspects of AM to consider when contemplating its potential role in host protection: 1) the up-regulation of AM expression in response to endotoxin and proinflammatory cytokines. 2) Its inherent capacity to auto-regulate the immune response mechanism either through a positive influence like recruitment of inactivated macrophages or through a negative influence by 

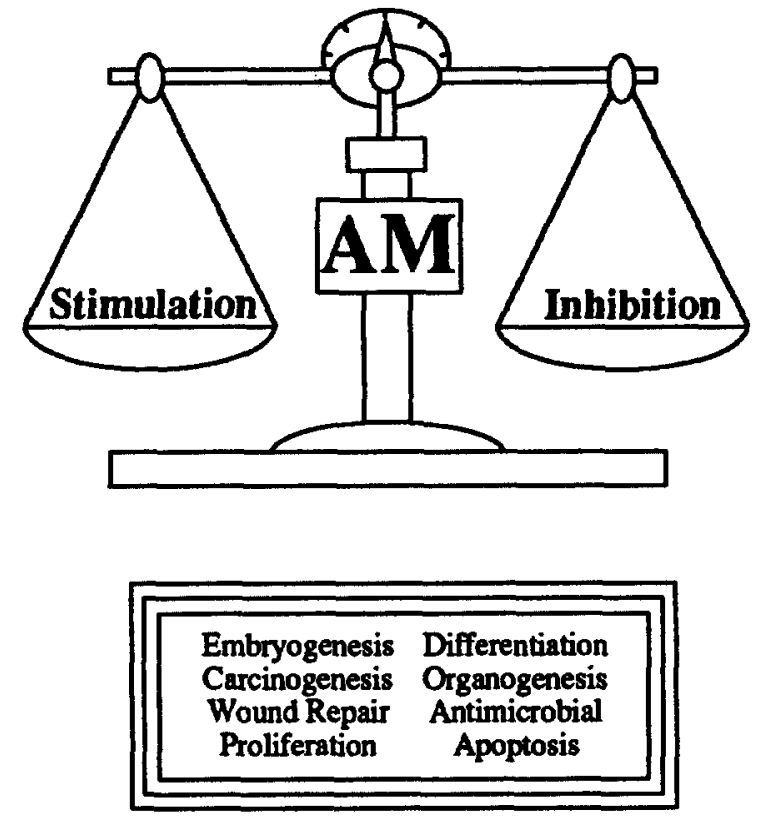

Figure 2. The involvement of adrenomedullin (AM) in maintaining a dynamic balance in growth regulatory pathways in which it can function either as a stimulator or an inhibitor of cell replication.

suppressing activated macrophage responses. 3) AM's antimicrobial action, which can cause direct lysis of certain microbial pathogens. 4) The ability of AM to drive the repair process of damaged tissue via its mitogenic and angiogenic characteristics. The pursuit and exploitation of these biological attributes may prove to be of immense value in the clinical setting.

\section{Conclusion}

In this paper, we have tried to give a general overview of AM's involvement in diverse physiological pathways as it relates to growth regulation. This peptide has been shown to be a highly conserved evolutionary molecule with origins dating back 100 million $\mathrm{yr}$ or more and therefore assumed to play a critical role in species survival. Although at first glance the AM field may appear somewhat esoteric, since its first introduction into the literature in 1993 by Kitamura et al. there have been over 600 publications written, two international symposia held and a comprehensive book released on this topic. This peptide has stimulated the interest of the multidisciplinary scientific community and global coverage regarding its investigative studies is increasing exponentially. In Table 1, we have cited examples in the literature which support AM as a mediator of growth regulation and have indicated its role in embryogenesis, wound repair, and carcinogenesis. Figure 2 illustrates the involvement of AM's complex biology in the maintenance of a dynamic balance associated with growth regulatory pathways. Adrenomedullin can have both a growth suppressive or growth proliferative function depending on the target cell examined and the environmental conditions in which the test is run. There are a variety of cytokines in which similar relationships have been identified, e.g., the diametric action of TGF- $\beta 1$ in growth control, in which its end response (proliferative/suppressive) is dependent on the in concert growth factor repertoire of the target cell and the receptor subtype availability (Roberts et al., 1985; Majack, 1987; Goodman and Majack, 1989). As we rapidly approach the beginning of a new century and questions on the role of $A M$ in growth regulation are addressed, it is predicted that this information will have a pivotal influence on clinical medicine and animal science as we know it today.

\section{Literature Cited}

Ando, K., N. Omi, T. Shimosawa, and T. Fujita. 1997. Proadrenomedullin $\mathrm{N}$-terminal 20 peptide (PAMP) inhibits proliferation of human neuroblastoma TGW cells. FEBS Lett. 413:462,-466

Barker, S., E. Wood, A.J.L. Clark, and R. Corder. 1998. Cloning of bovine preproadrenomedullin and inhibitions of its basal expression in vascular endothelial cells by staurosporine. Life Sci. 62:1407-1415.

Bechinger, B. 1997. Structure and functions of channel-forming peptides: Magainins, cecropins, melittin and alamethicin. J. Membrane Biol. 156:197-211.

Bogoyevitch, M. A., C. J. Marshall, and P. H. Sugdent. 1995. Hypertrophic agonist stimulates the activities of the protein kinases c-Raf and A-Raf in cultured ventricular myocytes. J. Biol. Chem. 270:26303-26310.

Chini, E. N., E. Choi, J. P. Grande, J. C. Burnett, and T. P. Dousa. 1995. Adrenomedullin suppresses mitogenesis in rat mesangial cells via cAMP pathway. Biochem. Biophys. Res. Commun. 215: 868-873.

Chini, E. N., C.S.C. Chini, E. Choi, J. C. Burnett, J. P. Grande, and T. P. Dousa. 1996. Adrenomedullin (ADM) inhibits mesangial cell (MC) proliferation induced by PDGF but not by endothelin (ET-1). J. Am. Soc. Nephrol. 7:1655.

Cook, S. J., and F. McCormick. 1993. Inhibition by cAMP of Rasdependent activation of Raf. Science 262:1069-1072.

Cornish, J., K. E. Callon, D. H. Coy, N. Y. Jiang, L. Xiao, G.J.S. Cooper, and I. R. Reid. 1997. Adrenomedullin is a potent stimulator of osteoblastic activity in vitro and in vivo. Am. J. Physiol. 273:E1113-E1120.

Cuttitta, F., M. J. Miller, L. Montuenga, M. Garayoa, T. Elsasser, T. Walsh, E. Unsworth, and A. Martínez. 1998. Adrenomedullin: Terra Incognita. In: A. Martínez and F. Cuttitta. (Eds.). Adrenomedullin. pp 1-26. IOS Press/Ohmsha Ltd., Amsterdam, The Netherlands.

Diamond, G., M. Zasloff, M. H. Eck, M. Brasseur, W. L. Maloy, and C. L. Bevins. 1991. Tracheal antimicrobial peptide, a cysteinerich peptide from mammalian tracheal mucosa: Peptide isolation and cloning of a cDNA. Proc. Natl. Acad. Sci. USA 88: 3952-3965.

Di Iorio, R., E. Marinoni, D. Scavo, C. Letizia, and E. V. Cosmi. 1997. Adrenomedullin in pregnancy. Lancet 349:328.

Di Iorio, R., E. Marinoni, and E. V. Cosmi. 1998. Adrenomedullin in pre-eclampsia. Lancet 351:676.

Dotsch, J., J. Hanze, V. Knufer, J. O. Steiss, K. Dittrich, A. Seidel, and W. Rascher. 1998. Increased urinary adrenomedullin excretion in children with urinary tract infection. Nephrol. Dial. Transpl. 13:1686-1689. 
Ebara, T., K. Miura, M. Okumura, T. Matsuura, S. Kim, T. Yukimura, and H. Iwao. 1994. Effect of adrenomedullin on renal hemodynamics and function in dogs. Eur. J. Pharmacol. 263: 69-73.

Eguchi, S., Y. Hirata, H. Kano, K. Sato, Y. Watanabe, T. X. Watanabe, K. Nakajima, S. Sakakibara, and F. Marumo. 1994a. Specific receptors for adrenomedullin in cultured rat vascular smooth muscle cells. FEBS Lett. 340:226-230.

Eguchi, S., Y. Hirata, H. Iwasaki, K. Sato, T. X. Watanabe, T. Inui, K. Nakajima, S. Sakakibara, and F. Marumo. 1994b. Structureactivity relationship of adrenomedullin, a novel vasodilatory peptide, in cultured rat vascular smooth muscle cells. Endocrinology 135:2454-2458.

Ehlenz, K., B. Koch, P. Preuss, B. Simon, I. Koop, and R. E. Lang. 1997. High levels of circulating adrenomedullin in severe illness: Correlation with C-reactive protein and evidence against the adrenal medulla as site of origin. Exp. Clin. Endocrinol Diabetes 105:156-162.

Fukuhara, M., T. Tsuchihashi, I. Abe, and M. Fujshima. 1995. Cardiovascular and neurohormonal effects of intravenous adrenomedullin in conscious rabbits. Am. J. Physiol. 269: R1289-R1293.

Fukuda, K., M. Onomura, H. Tsukada, T. Saito, M. Kodama, H. Nakamura, T. Taniguchi, M. Hosokawa, and Y. Seino. 1998. Adrenomedullin promotes the epithelial restitution of rat and human gastric mucosa in vitro. Gastroenterology 114:A125.

Gerbie, A. M., H. H. Hathaway, and J. I. Brewer. 1968. Autoradiographic analysis of normal trophoblastic proliferation. Am. J. Obstet. Gynecol. 100:640-648.

Goodman, L. V., and R. A. Majack. 1989. Vascular smooth muscle cells express distinct transforming growth factor $-\beta$ receptor phenotypes as a function of cell density in culture. J. Biol. Chem. 264:5241-5244.

Graham, C. H., and P. K. Lala. 1991. Mechanisms of control of trophoblast invasion in situ. J. Cell. Physiol. 148:228-234.

Graves, L. M., K. E. Bornfeldt, E. W. Raines, B. C. Potts, S. G. MacDonald, R. Ross, and E. G. Krebs. 1993. Protein kinase A antagonizes platelet-derived growth factor-induced signalling by mitogen-activated protein kinase in human arterial smooth muscle cells. Proc. Natl. Acad. Sci. USA 90:10300-10304.

Haneda, M., S. Araki, T. Sugimoto, D. Koya, and R. Kikkawa. 1996. Differential inhibition of mesangial MAP kinase cascade by cyclic nucleotides. Kidney Int. 50:384-391.

Harvey, M. B., K. J. Leco, M. Y. Arcellana-Panlilio, X. Zhang, D. R. Edwards, and G. A. Schultz. 1995. Proteinase expression in early mouse embryos is regulated by leukemia inhibitory factor and epidermal growth factor. Development 121:1005-1014.

Hata, T., K. Miyazaki, and K. Matsui. 1997. Decreased circulating adrenomedullin in pre-eclampsia. Lancet 350:1600.

Hirata, Y., C. Mitaka, K. Sato, T. Nagura, Y. Tsunoda, K. Amaha, and F. Marumo. 1996. Increased circulation adrenomedullin, a novel vasodilatory peptide, in sepsis. J. Clin. Endocrinol. Metab. 81:1449-1453.

Ichiki, Y., K. Kitamura, K. Kangawa, M. Kawamoto, H. Matsuo, and T. Eto. 1994. Distribution and characterization of immunoreactive adrenomedullin in human tissue and plasma. FEBS Lett. 338:6-10.

Ishimitsu, T., A. Miyata, H, Matsuoka, and K. Kangawa. 1998. Transcriptional regulation of human adrenomedullin gene in vascular endothelial cells. Biochem. Biophys. Res. Commun. 243:463-470.

Ishimitsu, T., M. Kojima, K. Kangawa, J. Hino, H. Matsuoka, K. Kitamura, T. Eto, and H. Matsuo. 1994. Genomic structure of human adrenomedullin gene. Biochem. Biophys. Res. Commun. 201:631-639.

Ishiyama, Y., K. Kitamura, Y. Ichiki, S. Nakamura, O. Kida, K. Kangawa, and Y. Eto. 1993. Hemodynamic effects of a novel hypotensive peptide, human adrenomedullin, in rats. Eur. J. Pharmacol. 241:271-273.
Ishizaka, Y., Y. Ishizaka, M. Tanaka, K. Kitamura, K. Kangawa, N. Minamino, H. Matsuo, and T. Eto. 1994. Adrenomedullin stimulates cyclic AMP formation in vascular smooth muscle cells. Biochem. Biophys. Res. Commun. 200:642-646.

Isumi, Y., N. Minamino, T. Katafuchi, M. Yoshioka, T. Tsuji, K. Kangawa, and H. Matsuo H. 1998a. Adrenomedullin production in fibroblasts: Its possible function as a growth regulator of Swiss 3T3 cells. Endocrinology 139:2552-2563.

Isumi, Y., H. Shoji, S. Sugo, T. Tochimoto, M. Yoshioka, K. Kangawa, H. Matsuo, and N. Minamino. 1998b. Regulation of adrenomedullin production in rat endothelial cells. Endoerinology 139:838-846.

Iwasaki, H., S. Eguchi, M. Shichiri, F. Marumo, and Y. Hirata. 1998. Adrenomedullin as a novel growth-promoting factor for cultured vascular smooth muscle cells: Role of tyrosine kinasemediated mitogen-activated protein kinase activation. Endocrinology 139:3432-3441.

Jahnke, G., A. Martínez, M. J. Miller, F. Cuttitta, A. Mitchell, M. Nelson, and K. Gray. 1996. Investigation of adrenomedullin expression in the mouse mammary gland and reproductive tract. In: Keystone Symposia, Breast and Prostate Cancer: Basic Mechanisms. Jan-Feb. p 35. Taos, New Mexico.

Jahnke, G. D., M. J. Miller, A. Martínez, L. Montuenga, and F. Cuttitta. 1997. Adrenomedullin expression in the mouse mammary gland: evidence for the mature form in milk. J. Mol. Endocrinol. 19:279-289.

Jougasaki, M. 1998. Autocrine role of the endothelin-B receptor in the secretion of endothelial derived adrenomedullin. GenBank, Accession Nol AF045773.

Jougasaki, M., C. M. Wei, L. L. Aarhus, D. M. Heublein, S. M. Sandberg, and J. C. Burnett. 1995. Renal localization and actions of adrenomedullin-A natriuretic peptide. Am. J. Physiol. 268:F657-F663.

Kanazawa, H., N. Kurihara, K. Hirata, K. S. Kudoh, T. Kawaguchi, and T. Tekeda. 1994. Adrenomedullin, a newly discovered hypotensive peptide, is a potent bronchodilator. Biochem. Biophys. Res. Commun. 205:251-254.

Kane, C.J.M., P. A. Hebda, J. N. Masnsbridge, and P. C. Hanawalt . 1991. Direct evidence for spatial and temporal regulation of transforming growth factor $\beta$-1 expression during cutaneous wound healing. J. Cell. Physiol. 148:157-173.

Kano, H., M. Kohno, K. Yasunari, K. Yokokawa, T. Horio, M. Ikeda, M. Minami, T. Hanehira, T. Takeda, and J. Yoshikawa. 1996. Adrenomedullin as a novel antiproliferative factor of vascular smooth muscle cells. J. Hypertension 14:209-213.

Kapas, S., D. W. Brown, P. M. Fathing, and E. Hagi-Pavli. 1997. Adrenomedullin has mitogenic effects on human oral keratinocytes: involvement of cyclic AMP. FEBS Lett. 418:287-290.

Kato, J., K. Kitamura, K. Kangawa, and T. Eto. 1995. Receptors for adrenomedullin in human vascular endothelial cells. Eur. J. Pharmacol. 289:383-385.

Kato, H., M. Shichiri, F. Marumo, and Y. Hirata. 1997. Adrenomedullin as an autocrine/paracrine apoptosis survival factor for rat endothelial cells. Endocrinology 138:2615-2620.

Kaufman, S., S. Jerat, and F. Lo. 1998. Adrenomedullin (ADM) and nitric axide in pregnancy-role of $5 \alpha$-OH-dihydroprogesterone ( $5 \alpha$-OH-DHP). FASEB J. 12:A99.

Kitamura, K., K. Kangawa, M. Kawamoto, Y. Ichiki, S. Nakamura, H. Matsuo, and T. Eto. 1993a. Adrenomedullin: A novel hypotensive peptide isolated from human pheochromocytoma. Biochem. Biophys. Res. Commun. 192:553-560.

Kitamura, K., K. Kangawa, M. Kojima, Y. Ichiki, H. Matsuo, and Y. Eto. 1994. Complete amino acid sequence of porcine adrenomedullin and cloning of cDNA encoding its precursor. FEBS Lett. 338:306-310.

Kitamura, K., K. Kangawa, H. Matsuo, and T. Eto. 1998. Structure and function of adrenomedullin and PAMP. In: A. Martínez and F. Cuttitta (Eds.). Adrenomedullin. p 27. IOS Press/Ohmsha Ltd., Amsterdam, The Netherlands. 39. 
Kitamura, K., J. Sakata, K. Kangawa, M. Kojima, H. Matsuo, and T. Eto. 1993b. Cloning and characterization of cDNA encoding a precursor for human adrenomedullin. Biochem. Biophys. Res. Commun. 194:720-725.

Kobayashi, S., T. Shikasho, J. Nishimura, Y. Kureish, and H. Kanaide. 1995. Adrenomedullin stimulates the cell cycle progression and the expression of $c$-fos mRNA in vascular smooth muscle cells in primary culture. Circulation 92: 1.694-1.695.

Kubo, A., N. Minamino, Y. Isumi, K. Kangawa, K. Dohi, and H. Matsuo. 1998a. Adrenomedullin production is correlated with differentiation in human leukemia cell lines and peripheral blood monocytes. FEBS Lett. 462:233-237.

Kubo, A., N. Minamino, Y. Isumi, T. Katafuchi, K. Kangawa, K. Dohi, and H. Matsuo. 1998b. Production of adrenomedullin in macrophage cell lines and peritoneal macrophage. J. Biol. Chem. 273:16730-16738.

Lauria, M. R., C. Standley, Y. Sorokin, and D. Cotton. 1996a. Adrenomedullin levels in normal and preeclamptic pregnancies at term. Am. J. Obstet. Gynecol. 176:S103.

Lauria, M. R., C. Standley, Y. Sorokin, and D. Cotton. 1996b. Adrenomedullin by trimester in preeclamptic versus normal pregnancy. Am. J. Obstet. Gynecol. 176:S104.

Lippton, H., J.-K. Chang, Q. Hao, W. Summer and A. L. Hyman 1994. Adrenomedullin dilates the pulmonary vascular bed in vivo. J. Appl. Physiol. 76:2154-2156.

López Diez Del Corral, J. and N. Cuesta Rubio. 1998. Adrenomedullin in non-mammalian vertebrate pancreas. In: A. Martínez and F. Cuttitta (Eds.). Adrenomedullin. pp 247-248. IOS Press/ Ohmsha Ltd., Amsterdam, The Netherlands.

Macri, C., D. Loup, M. McHale, R. Jacobs, L. Bales, M. Sundborg, A. Armstrong, D. Gehlbach, A. Mitchell, M. Nelson, C. Macri, M. J. Miller, A. Martínez, F. Cuttitta, and K. Gray. 1998. Adrenomedullin is widely expressed throughout normal and abnormal reproductive tissues of women. In: A. Martínez and F. Cuttitta (Eds.). Adrenomedullin. pp 207-226. IOS Press' Ohmsha Ltd., Amsterdam, The Netherlands.

Macri, C. J., A. Martínez, T. W. Moody, K. D. Gray, M. J. Miller, M. Gallagher, and F. Cuttitta. 1996a. Detection of adrenomedullin, a hypotensive peptide, in amniotic fluid and fetal membranes. Am. J. Obstet. Gynecol. 175:906-911.

Macri, C., M. Miller, K. Gray, M. Gallagher, A. Martínez, and F. Cuttitta. 1996b. Adrenomedullin, a new hypotensive peptide is expressed in maternal decidual cells and fetal cells in first trimester of pregnancy. Am. J. Obstet. Gynecol. 176:S155.

Majack, R. A. 1987. Beta-type transforming growth factor specifies organizational behavior in vascular smooth muscle cell cultures. J. Cell. Biol. 105:467-471.

Majid, D. S., P. J. Kadowitz, D. H. Coy and L. G. Navar. 1996. Renal responses to intraarterial administration of adrenomedullin in dogs. Am. J. Physiol. 270:F200-F205.

Martínez, A., T. Elsasser, C. Muro-Cacho, T. W. Moody, M. J. Miller, C. Macri, and F. Cuttitta. 1997a. Expression of adrenomedullin and its receptor in normal and malignant human skin: A potential pluripotent role in the integument. Endocrinology 138:5597-5604.

Martínez, A., M. J. Miller, K. J. Catt, and F. Cuttitta. 1997b. Adrenomedullin receptor expression in human lung and in pulmonary tumors. J. Histochem. Cytochem. 45:159-164.

Martínez, A., A. J. Miller, J. López, V. Martínez, Y. Taché, and F. Cuttitta. 1996a. A new endocrine cell type in the rat stomach: Adrenomedullin-producing cells. 10th Int. Cong. Endocrinol. June 12-13. p 974. San Francisco, CA.

Martínez, A., M. J. Miller, L. M. Montuenga, and F. Cuttitta. 1998 Adrenomedullin regulates hormone secretion. In: A. Martínez and F. Cuttitta (Eds). Adrenomedullin. pp 185-196. IOS Press/ Ohmsha Ltd., Amsterdam, The Netherlands.

Martínez, A., M. J. Miller, E. J. Unsworth, J. M. Siegfried, and F. Cuttitta. 1995. Expression of adrenomedullin in normal human lung and in pulmonary tumors. Endocrinology 136:4099-4105.
Martínez, A., C. Weaver, J. López, S. J. Bhathena, T. H. Elsasser, M. J. Miller, T. W. Moody, E. J. Unsworth, and F. Cuttitta. 1996b. Regulation of insulin secretion and blood glucose metabolism by adrenomedullin. Endocrinology 137:2626-2632.

Martínez, V., F. Cuttitta, and Y. Taché. 1997c. Central action of adrenomedullin to inhibit gastric emptying in rats. Endocrinology 138:3749-3755.

Matousovic, K., J. P. Grande, C.C.S. Chin, E. N. Chini, and T. P. Dousa. 1995. Inhibitors of cyclic nucleotide phosphodiesterase isozymes type-III an type-IV suppress mitogenesis of rat mesangial cells. J. Clin. Invest. 96:401-410.

Marx, J. 1993. Two major signal pathways linked. Science 262: 988-989.

Michibata, H., M. Mukoyama, I. Tanaka, S. I. Suga, M. Nakagawa, R. Ishibashi, M. Goto, K. Akaji, Y. U. Fujiwara, Y. Kiso, and K. Nakao. 1998. Autocrine/paracrine role of adrenomedullin in cultured endothelial and mesangial cells. Kidney Int. 53: 979-985.

Michibata, H., M. Mukoyama, I. Tanaka, S. Suga, M. Nakaqawa, R. Ishibashi, M. Goto, M. Kasahara, K. Akaji, Y. Fujiwara, Y. Kiso, and K. Nakao. 1996. Role of adrenomedullin as an autocrine/paracrine regulator of vascular and mesangial cell growth. J. Am. Soc. Nephrol. 7:1638.

Michibata, H., M. Mukoyama, I. Tanaka, M. Goto, M. Nakagawa, R. Ishibashi, S. Suga, K. Akaji, K. Y. Fujiwara, Y. I. Kiso, and K. Nakao. 1995. Production of adrenomedullin (AM) in cultured mesangial cells revealed by a specific monoclonal antibody to AM. J. Amer. Soc. Nephrol. 6:741.

Miller, M. J., A. Martínez, L. M. Montuenga, M. Garayoa, T. Moody, E. Unsworth, and F. Cuttitta. 1998. Adrenomedullin: A pluripotent peptide with growth regulatory function. In: A. Martinez and F. Cuttitta (Eds.). Adrenomedullin. pp 171-183. IOS Press/Ohmsha Ltd., Amsterdam, The Netherlands.

Miller, M. J., A. Martínez, E. J. Unsworth, C. J. Thiele, T. W. Moody, T. Elsasser, and F. Cuttitta. 1996. Adrenomedullin expression in human tumor cell lines. Its potential role as an autocrine growth factor. J. Biol. Chem. 271:23345-23351.

Minamino, N., Y. Isumi, K. Kangawa, K. Kitamura, and H. Matuso. 1998. Adrenomedullin production in vascular cells and its function in the vascular wall. In: A. Martínez and F. Cuttitta (Eds.). Adrenomedullin. pp 79-102. IOS Press/Ohmsha Ltd., Amsterdam, The Netherlands.

Moody, T. W., M. J. Miller, A. Martínez, E. Unsworth, and F. Cuttitta. 1997. Adrenomedullin binds with high affinity, elevates cyclic AMP, and stimulates c-fos mRNA in C6 glioma cells. Peptides 18:1111-1115.

Montuenga, L. M., J. M. Mariano, M. A. Prentice, F. Cuttitta, and S. B. Jakowlew. 1998. Coordinated expression of transforming growth factor- $\beta 1$ and adrenomedullin in rodent embryogenesis. Endocrinology 139:3946-3957.

Montuenga, L. M., A. Martínez, M. J. Miller, E. J. Unsworth, and F. Cuttitta. 1997. Expression of adrenomedullin and its receptor during embryogenesis suggests autocrine or paracrine modes of action. Endocrinology 138:440-451.

Morrish, D. W., D. Bhardwaj, L. K. Dabbagfh, H. Marusyk, and O. Siy. 1987. Epidermal growth factor induces differentiation and secretion of human chorionic gonadotropin and placental lactogen in normal human placenta. J. Clin. Endocrinol. Metabol. 65:1282-1290.

Morrish, D. W., E. Linetsky, D. Bhardwaj, H. Li, J. Dakour, R. G. Marsh, M. C. Paterson, and R. Godbout. 1996. Identification by subtractive hybridization of a spectrum of novel and unexpected genes associated with in vitro differentiation of human cytotrophoblast cells. Placenta 17:431-441.

Mulder, H., B. Ahrén, S. Karlsso, and F. Sundler. 1996. Adrenomedullin: Localization in the gastrointestinal tract and effects on insulin secretion. Reg. Peptide 62:107.

Murphy, T. C., and W. K. Samson. 1995. The novel vasoactive hormone, adrenomedullin, inhibits water drinking in the rat. Endocrinology 136:2459-2463. 
Nakayama, M., K. Takahashi, O. Murakami, K. Shirato, and S. Shibahara. 1998. Induction of adrenomedullin by hypoxia and cobalt chloride in human colorectal carcinoma cells. Biochem. Biophys. Res. Commun. 243:39-44.

Nishio, K., Y. Akai, Y. Murao, N. Doi, S. Ueda, H. Tabuse, S. Miyamoto, K. Dohi, N. Minamino, H. Shoji, K. Kitamura, K. Kangawa, and H. Matsuo. 1997. Increased plasma concentrations of adrenomedullin correlate with relaxation of vascular tone in patients with septic shock. Crit. Care Med. 25:953-957.

Nuki, C., H. Kawasaki, K. Kitamura, M. Takenaga, K. Kangawa, T. Eto, and A. Wada. 1993. Vasodilator effect of adrenomedullin and calcitonin gene-related peptide. Biochem. Biophys. Res. Commun. 196:245-251.

Okazaki, T., Y. Olgawa, N. Tamura, K. Mori, N. Isse, T. Aoki, J. M Rochelle, M. M. Taketo, and K. Nakao. 1996. Genomic organization, expression, and chromosome mapping of the mouse adrenomedullin gene. Genomics 37:395-399.

Parkes, D. G. 1995. Cardiovascular actions of adrenomedullin in conscious sheep. Am. J. Physiol. 268:H2574-H2578.

Peters, M. A., X. Wang, and E. J. Taparowsky. 1997. The promoter of the adrenomedullin precursor gene is downregulated in cells overexpressing the v-myc protein. NCI Adrenomedullin Symposium, September 3-5. p 4. Bethesda, MD.

Ray, J. M., and W. G. Stetler-Stevenson. 1994. The role of matrix metalloproteases and their inhibitors in tumour invasion, metastasis, and angiogenesis. Eur. Respir. J. 7:2062-2072.

Roberts, A. B., M. A. Anzano, L. M. Wakefield, N. S. Roche, D. F. Stern, and M. B. Sporn. 1985. Type beta transforming growth factor: a bifunctional regulator of cellular growth. Proc. Natl. Acad. Sci. USA 82:119-123.

Roberts, A. B., M. B. Sporn, R. K. Assoian, J. M. Smith, N. S. Roche, L. M. Wakefield, U. I. Heine, L. A. Liotta, V. Falanga, J. H. Kehrl, and A. S. Fauci. 1986. Transforming growth factor type beta: rapid induction of fibrosis and angiogenesis in vivo and stimulation of collagen formation in vitro. Proc. Natl. Acad. Sci. USA 83:4167-4171.

Ryan, H. E., J. Lo, and R. S. Johnson. 1998. HIF-1 $\alpha$ is required for solid tumor formation and embryonic vascularization. EMBO J. 17:3005-3015.

Sakata, J., T. Shimokubo, K. Kitamura, S. Nakamura, K. Kangawa, H. Matsuo, and T. Eto. 1993. Molecular cloning and biological activities or rat adrenomedullin, a hypotensive peptide. Biochem. Biophys. Res. Commun. 195:921-927.

Sakata, J., T. Shimokubo, K. Kitamura, M. Nishizono, Y. Iehiki, K. Kangawa, H. Matsuo, and T. Eto. 1994. Distribution and characterization of immunoreactive rat adrenomedullin in tissue and plasma. FEBS Lett. 352:105-108.

Samson, W. K., and T. C. Murphy. 1997. Adrenomedullin inhibits salt appetite. Endocrinology 138:613-616.

Samson, W. K., T. C. Murphy, and D. A. Schell. 1995. A novel vasoactive peptide, adrenomedullin, inhibits pituitary adrenocorticotropin release. Endocrinology 136:2349-2352.

Santiago, J. A., E. A. Garrison, V. L. Ventura , D. H. Coy, K. Bitar, W. A. Murphy, D. B. McNamara, and P. J. Kadowitz. 1994. Synthetic human adrenomedullin and adrenomedullin 15-52 have potent short-lived vasodilator activity in the hindlimb vascular bed of the cat. Life Sci. 55:PL85-PL90.

Sato, A., and D. Autelitano. 1995. Adrenomedullin induces expression of c-fos and AP-1 activity in rat vascular smooth muscle cells and cardiomyocytes. Biochem. Biophys. Res. Commun. 217:211-216.

Satoh, F., K. Takahashi, O. Murakami, K. Totsune, M. Sone, M. Ohneda, K. Abe, Y. Miura, Y. Hayshi, H. Sasano, and T. Mouri. 1995. Adrenomedullin in human brain, adrenal-glands and tumor-tissues of pheochromocytoma, ganglioneuroblastoma and neuroblastoma. J. Clin. Endocrinol. Metabol. 80:1750-1752.

Satoh, F., K. Takahashi, O. Murakami, K. Totsune, M. Sone, M. Ohneda, K. Abe, Y. Miura, and T. Mouri. 1997. Immunoreactive adrenomedullin in human adrenal glands and adrenal tumors. Cancer Detect. Prev. 21:51-54.
Schonwetter, B. S, E. D. Stolzenberg, and M. A. Zasloff. 1995. Epithelial antibiotics induced at sites of inflammation. Science 267:1645-1648.

Segawa, K., K. Minami, T. Sata, A. Kuroiwa, and A. Shigematsu. 1996. Inhibitory effect of adrenomedullin of rat mesangial cell mitogenesis. Nephron 74:577-579.

Sevetson, B. R., X. Kong, and J. C. Lawrence. 1993. Increasing cAMP attenuates activation of mitogen-activated protein kinase. Proc. Natl. Acad. Sci. USA 90:10305-10309.

Shimekake, Y., K. Nagata, S. Ohta, Y. Kambayashi, H. Teraoka, K. Kitamura, T. Eto, K. Kangawa, and H. Matsuo. 1995. Adrenomedullin stimulates two signal transduction pathways, cAMP accumulation and $\mathrm{Ca}^{2+}$ mobilization, in bovine aortic endothelial cells. J. Biol. Chem. 270:4412-4417.

Shoji, H., N. Minamino, K. Kangawa, and H. Matsuo. 1995. Endotoxin markedly elevates plasma concentration and gene transcript of adrenomedullin in rat. Biochem. Biophys. Res. Commun. 215:531-537.

So, S., Y. Hattori, K. Kasai, S. I. Shimoda, and S. S. Gross. 1996. Upregulation of rat adrenomedullin gene expression by endotoxin Relation to nitric oxide synthesis. Life Sci. 58:309-315.

Sugo, S., N. Minamino, K. Kangawa, K. Miyamoto, K. Kitamura, J. Sakata, T. Eto, and H. Matsuo. 1994a. Endothelial cells actively synthesize and secrete adrenomedullin. Biochem. Biophys. Res. Commun. 201:1160-1166.

Sugo, S., N. B. Minamino, H. Shoji, K. Kangawa, K. Kitamura, T. Eto, and H. Matsuo. 1994b. Production and secretion of adrenomedullin from vascular smooth muscle cells: Augmented production by tumor necrosis factor- $\alpha$. Biochem. Biophys. Res. Commun. 203:719-726.

Sugo, S., N. Minamino, H. Shoji, K. Kangawa, K. Kitamura, T. Eto, and H. Matsuo. 1995. Interleukin-1, tumor necrosis factor and lipopolysaccharide actively stimulates production of adrenomedullin in vascular smooth muscle cells. Biochem. Biophys. Res. Commun. 207:25-32.

Takahashi, H., T. X. Watanabe, M. Nishimura, T. Nakanishi, M. Sakamoto, M. Yoshimaura, Y. Komijama, M. Masuda, and T. Murakami. 1994. Centrally induced vasopressor and sympathetic responses to a novel endogenous peptide, adrenomedullin, in anesthetized rats. Am. J. Hypertens. 7 $478-482$.

Takahashi, K., F. Satoh, E. Hara, M. Sone, O. Murakami, T Kayama, T. Yoshimoto, and S. Shibahara. 1997. Production and secretion of adrenomedullin from glial cell tumors and its effects on cAMP production. Peptide 18:1117-1124.

Tomikawa, M., H. Wang, M. K. Jones, K. Sugimachi, I. J. Sarfeh and A. S. Tarnawski. 1998. Expression of adrenomedullin in portal hypertensive gastric mucosa of rats. J. Physiol. Pharmacol. 49:319-328.

Walsh, T. J., A. Martínez, J. Peter, M. J. Miller, C. A. Lyman, J. A. Bengoechea, T. Jacks, A. DeLucca, M. Rudel, T. Elsasser, E. Unsworth, and F. Cuttitta. 1998. Mechanisms of action of the novel antimicrobial peptide adrenomedullin and its generelated peptides. 12th Annual Meeting of the Infectious Diseases Society of America. November 12-14. p 250. Denver, CO.

Walsh, T. J., A. Martínez, J. Peter, E. Unsworth, and F. Cuttitta. 1996. Antimicrobial activity of adrenomedullin and its gene related peptides. Clin. Infect. Dis. 23:877.

Wang, H., M. Tomikawa, I. J. Sarfeh , and A. Tarnawski. 1998 Ethanol injury triggers activation of adrenomedullin and its receptor genes in gastric mucosa bordering necrosis: A key to mucosal repair? Gastroenterology 114:A327.

Wang, X., M. Peters, and E. J. Taparowsky. 1996a. The adrenomedullin precursor gene is potential cellular target for regulation by the v-myc protein complex. Mol. Biol. Cell 7:468a.

Wang, X., M. Peters, and E. J. Taparowsky. 1996b. Identification of the adrenomedullin precursor gene as a potential cellular target for regulation by the v-myc protein complex. 12th Annual Meeting on Oncogenes, July 18-22. p 259. Hood College, Frederick, MD. 
Washimine, H., Y. Asada, K. Kitamura, Y. Ichiki, S. Hara, Y. Yamamoto, K. Kangawa, A. Sumiyoshi, and T. Eto. 1995. Immunohistochemical identification of adrenomedullin in human, rat and porcine tissue. Histochem. Cell Biol. 103:251-254.

Withers, D. J., H. A. Coppock, T. Seufferlein, D. M. Smith, S. R. Bloom, and E. Rozengurt. 1996. Adrenomedullin stimulates DNA synthesis and cell proliferation via elevation of cAMP in Swiss 3T3 cells. FEBS Lett. 378:83-87.

Wu, J., P. Sent, T. Jelinek, A. Wolfman, M. J. Weber, and T. W. Sturgill. 1995. Inhibition of the EGF-activated MAP kinase signalling pathway by adenosine $3^{\prime} 5^{\prime}$ monophosphate. Science 262:1069-1072.

Yagel, S., R. S. Parhar, J. J. Jeffrey, and P. K. Lala. 1988. Normal nonmetastatic trophoblast cells share in vitro invasive properties of malignant cells. J. Cell. Physiol. 136:455-462.
Yamaguchi, T., K. Baba, Y. Doi, and K. Yano. 1995. Effect of adrenomedullin on aldosterone secretion by dispersed rat adrenal zona glomerulosa cells. Life Sci. 56:379-387.

Zaks-Zilberman, M., C. A. Solkowski, T. Elsasser, F. Cuttitta, and S. N. Vogel. 1998. Induction of adrenomedullin mRNA and protein by lipopolysaccharide and paclitaxel ( Taxol) in murine macrophages. Infect. Immun. 66:4669-4675.

Zasloff, M. 1987. Magainins, a class of antimicrobial peptides from Xenopus skin: Isolation, characterization of two active forms, and partial cDNA sequence of a precursor. Proc. Natl. Acad. Sci. USA 84:5449-5453.

Zhao, Y., S. Hague, S. Manek, L. Zhang, R. Bicknell, and M.C.P. Rees. 1998. PCR display identifies tamoxifen induction of the novel angiogenic factor adrenomedullin by an nonestrogenic mechanism in the human endometrium. Oncogene 16:409-415. 